\title{
Pelatihan Pengelolaan Manajemen Keuangan dan Pelaporan Keuangan Akuntansi Pesantren bagi Pengelola Yayasan Pondok Pesantren X di Kota Semarang
}

\section{Training of Financial Management and Financial Statement of Boarding School Accounting for Manager at X Boarding School Foundation in Semarang}

\author{
Asih Niati, Yohanes Suhardjo, Ratna Wijayanti, Risti Ulfi Hanifah \\ Fakultas Ekonomi, Universitas Semarang \\ asih_niat@usm.ac.id
}

Riwayat Artikel: Dikirim 1 April 2019; Diterima 26 November 2019; Diterbitkan 30 November 2019

\begin{abstract}
Abstrak
Pondok pesantren merupakan salah satu lembaga pendidikan organisasi nirlaba keagamaan non pemerintah yang mengedepankan suatu pelayanan pada pihak eksternal. Pengelolaan pondok pesantren masih menggunakan manajemen yang sederhana dan dalam pengelolaan keuangan hanya dibebankan pada satu orang pengelola yaitu bendahara, akuntansi yang selama ini dilakukan kurang menggunakan laporan keuangan yang sesuai dengan pedoman Akuntansi Pesantren. Tujuan dari pengabdian ini adalah memberikan tambahan pengetahuan kepada para pengelola sehingga dapat melakukan manajemen modern dengan pengelolaan sumber-sumber pendanaan yang dapat memberikan pelaporan secara transparan, akuntabel dan dapat dipertanggujawabkan. Metode pelaksanaan kegiatan adalah penyuluhan atau ceramah, diskusi dan tanya jawab, yang diawali dengan memberikan pengetahuan tentang pentingnya pengelolaan manajemen keuangan pondok pesantren yang transparan, dimengerti dan dapat digunakan atau dibaca kepada semua pihak yang membutuhkan. Dengan diadakannya kegiatan Pengabdian Kepada Masyarakat maka dapat menambah wawasan, pengetahuan dan pemahaman serta meningkatkan pemahaman tentang manajemen keuangan dan pelaporan keuangan yang transparan dan akuntabel.
\end{abstract}

Kata kunci: manajemen pondok pesantren dan pelaporan keuangan

\begin{abstract}
Islamic boarding schools are one of the educational institutions of non-profit and non-governmentalreligiousorganizations that prioritize service on external parties. The management of Islamic boarding schoolscurrently uses a simple management technique and they charged the financial managementonly to a treasurer, the current accounting has not usedfinancial statement which is according to Islamic Boarding Accounting guidelines. The purpose of this public service is to provide additional knowledge to the managersso be can carry out modern management by managing sources of funding so be can provide a transparentand accountable report. The method to implement the agenda are counseling or lecture, discussion and question and answer section, which begins byproviding knowledge about the importance of managing the financial management of boarding schools that aretransparent, understandable and can be used or read to all parties in need.By holding community service activities, it can add insight,knowledge and understanding as well as increase the understanding of financial management andtransparent as well as accountable financial statement.
\end{abstract}

Keywords: boarding school management and financial statement

\section{PENDAHULUAN}

\section{Latar Belakang Masalah}

Pondok Pesantren X merupakan yayasan yang terletak di Kota Semarang - Jawa Tengah. Saat ini memiliki 1700 para santri dan mempunyai beberapa pengelolaan usaha.
Berdasarkan survey yang ada dilapangan Pondok Pesantren X sudah menunjukkan adanya pengelolaan manajemen dan laporan keuangan dengan baik, akan tetapi permasalahan yang telah ada, bahwa pengelolaan manajemen keuangannya masih menggunakan system 
secara sederhana dan masih bersifat konvensional, apalagi dalam pengelolaan keuangan belum mengacu pada PSAK 45: Akuntansi Pesantren yang berlaku, sehingga laporan keuangan tersebut belum memberikan informasi yang dibutuhkan oleh para pemberi dana secara terperinci. Adapun permasalahan dapat dilihat pada tabel 1 dibawah ini sebagai berikut :

Tabel 1.

Permasalahan Pondok Pesantren

\begin{tabular}{|c|c|c|}
\hline $\mathrm{No}$ & Keterangan & Permasalahan \\
\hline 1 & $\begin{array}{l}\text { Sumber Daya } \\
\text { Manusia } \\
\text { (SDM) }\end{array}$ & $\begin{array}{l}\text { Keterbatasan kualitas } \\
\text { sumber daya manusia } \\
\text { sehingga pengelolaan } \\
\text { manajemen masih } \\
\text { bersifat sederhana }\end{array}$ \\
\hline 2 & Anggaran & $\begin{array}{lr}\text { Minimnya } & \text { dana } \\
\text { operasional, } & \text { yang } \\
\text { berakibat } & \text { pada } \\
\text { kendala } & \text { dalam } \\
\text { melakukan } & \text { proses } \\
\text { aktifitas } & \text { dan } \\
\text { pengembangan } & \\
\text { pesantren } & \text { setiap } \\
\text { harinya. } & \end{array}$ \\
\hline 3 & Pelaporan & $\begin{array}{l}\text { Perputaran keuangan } \\
\text { di pondok pesantren } \\
\text { cenderung tertutup } \\
\text { sehingga pelaporan } \\
\text { keuangan yang } \\
\text { akuntabel dan } \\
\text { transparan juga } \\
\text { terabaikan. } \\
\text { Belum menggunakan } \\
\text { Laporan Keuangan } \\
\text { sesuai PSAK 45: } \\
\text { Akuntansi Pondok } \\
\text { Pesantren. }\end{array}$ \\
\hline
\end{tabular}

Pada umumnya praktik manajemen yang ada masih sangat sederhana dan pengelolaan sebagian dijalankan oleh para santri sedangkan dalam praktek akuntansi yang selama ini dilakukan kurang menggunakan laporan keuangan yang sesuai, masih terprioritas pada kualitas program seperti pondok pesantren yang lain (Wahyuningsih, 2018) sehingga tidak dapat menjadi bahan perbandingan dan tidak dapat digunakan sebagai bahan acuan oleh pihak eksternal.

Dalam rangka upaya memberdayakan perekonomian pondok pesantren yang mampu menyusun laporan keuangan sesuai dengan aturan Standar Akuntansi yang berlaku di Indonesia maka Ikatan Akuntan Indonesia dan Bank Indonesia membuat dan menerbitkan Pedoman Akuntansi Pesantren yang diharapkan nanti semua pondok pesantren dapat menjalankan laporan keuangan sesuai dengan standar akuntansi yang berlaku yang transparan, akuntabilitas dan efektivitas (Arifin, 2016)

\section{Permasalahan Mitra}

Berdasarkan hasil analisis situasi di atas, maka permasalahan mitra dapat diidentifikasi sebagai berikut:

1. Keterbatasan kualitas sumber daya manusia sehingga pengelolaan manajemen masih bersifat sederhana.

2. Minimnya dana operasional, sehingga akan berakibat pada kendala dalam melakukan proses aktifitas dan pengembangan pesantren setiap harinya.

3. Pengelola Pondok pesantren dalam melakukan penyusunan laporan keuangan belum disesuaikan dengan standard akuntansi yang ada, pelaporannya masih berbentuk secara sederhana.

\section{METODE}

\section{Pelaksanaan}

Metode pelaksanakan kegiatan pengabdian ini berupa penyuluhan, diskusi dan tanya jawab, dimana tim pengabdian mengawali kegiatan dengan memberikan pengetahuan tentang pentingnya pengelolaan manajemen keuangan pondok pesantren yang transparan, dimengerti dan dapat digunakan atau dibaca kepada semua pihak yang membutuhkan.

Metode penyuluhan berkaitan dengan pemberian pengetahuan mengenai Manajemen Keuangan (Martono, 2010),Pedoman Akuntansi Pesantren dan pelaporan keuangan setelah itu dilanjutkan metode sharing dan diskusi, kemudian diakhiri dengan materi contoh penyusunan laporan keuangan kepada para peserta. 


\section{Evaluasi}

Evaluasi program dilaksanakan dengan membandingkan keadaan peserta sebelum dan sesudah program kegiatan pengabdian dilaksanakan. Keberhasilan program ditujukan dengan adanya perubahan yang positif dari keadaan mitra yaitu peningkatan pengetahuan tentang manajemen keuangan, penyusunan laporan keuangan serta aturan pedoman akuntansi pesantren.

\section{Metode Pendekatan}

Dalam rangka mencapai tujuan dari pengabdian ini maka tim pengabdian melakukan upaya dengan menggunakan metode pendekatan participatory training, yaitu pendekatan yang menekankan pada partisipasi penuh dari mitra melalui beberapa langkah pembelajaran dalam bentuk penyuluhan dan pelatihan.

\section{HASIL DAN PEMBAHASAN}

\section{Hasil Pelaksanaan}

Kegiatan Pengabdian Kepada Masyarakat dilaksanakan pada hari Sabtu tanggal 12 Januari 2018 dengan peserta dari pengelola pondok pesantren X.

Pelaksanaan kegiatan tersebut diawali dengan perkenalan dan maksud dari tujuan melakukan pengabdian kemudian memberikan pengetahuan dan pelatihan bagaimana melakukan pengelolaan manajemen keuangan pondok pesantren yang baik serta membuat ilustrasi pelaporan keuangan sesuai PSAK.

\section{Evaluasi Pelaksanaan Kegiatan Pengabdian Kepada Masyarakat}

Hasil evalusi pelaksanaan kegiatan pengabdian kepada masyarakat yaitu kegiatan telah berjalan dengan lancar dan banyak peserta yang hadir dalam kegiatan ini. Para peserta telah mengikuti seluruh program kegiatan pengabdian mulai dari pembukaan, penyuluhan manajemen keuangan, manajemen keuangan pondok pesantren dan pedoman akuntansi pondok pesantren sesuai Standar Akuntansi Keuangan Entitas Tanpa Akuntabilitas Publik (SAK ETAP) sampai penutup.
Adapun gambaran pelaksanaan pengabdian kepada masyarakat dapat dilihat pada gambar di bawah ini:

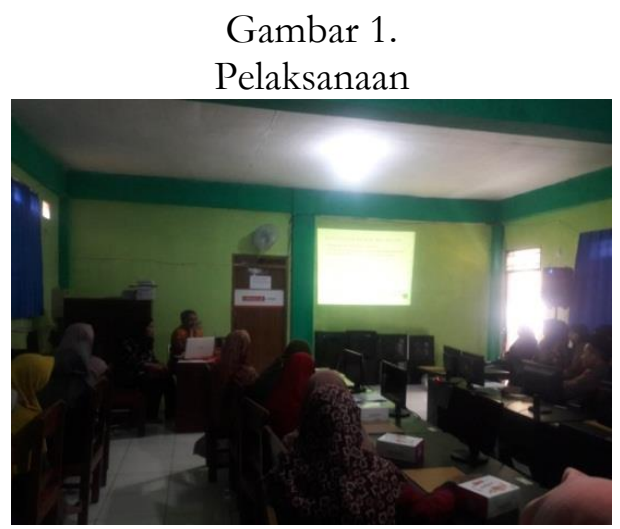

(a)

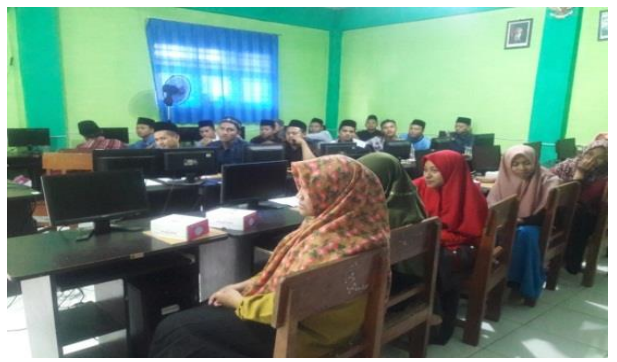

(b)

\section{KESIMPULAN DAN SARAN \\ Kesimpulan}

Kegiatan pengabdian kepada masyarakat yang dilaksanakan oleh tim Fakultas Ekonomi Universitas Semarang telah berjalan sesuai rencana yang dihadiri oleh 14 peserta dan hasil yang dicapai adalah adanya peningkatan pemahaman mengenai pengelolaan manajemen yang baik di pondok pesantren dan diupayakan dilakukan perbaikan sistem dalam Pedoman pengelolaan pembayaran, pembukuan dan pencatatan (Hartono, Pedoman Pencatatan Transaksi Keuangan Pesantren. , 2018).

\section{Saran}

Saran yang dapat disampaikan oleh tim pengabdian yaitu dari hasil pengabdian ini secara rutin pengelola dapat mengaplikasikan pengetahuan yang di dapat pada saat memproses dan membuat laporan keuangan pondok pesantren melalui pencatatan, pembukuan dan pelaporan yang 
sesuai dengan standar PSAK dan diperlukan system pengelolaan manajemen dengan menggunakan system teknologi berupa program (Iman Firman H, 2016) (Yahya, 2015) sehingga dengan mudah dapat dipakai untuk memberikan laporan kepada masyarakat yang membutuhkan atau pihak yang berkepentingan terhadap laporan keuangan yang transparan, akuntabel dan dapat dipertanggunjawabkan.

Dengan mempertimbangkan asset yang dimiliki oleh pondok pesantren maka pengelola pondok pesantren perlu diberikan pengetahuan secara rutin berupa pelatihan pengelolaan keuangan sehingga diharapkan mampu untuk menyusun laporan keuangan sesuai dengan standar akuntansi keuangan yang berlaku umum di Indonesia ( Pernyataan Standar Akuntansi Keuangan (PSAK), 2002)

\section{DAFTAR PUSTAKA}

Arifin, M. (2016). Manajemen Keuangan Pondok Pesantren Gratis. Jurnal Pendidikan dan Manajemen Islam FIKROTUN Vol 4 No. 2 .

Hartono, P. (2018, Agustus 25). Pedoman Pencatatan Transaksi Kenangan Pesantren. . Retrieved from http://www.iaiglobal.or.Id/v/files/file -publikasi /Pedoman Akuntansi Pesantren 2002052018.pdf.

Iman Firman H, R. M. (2016). Pelatihan Managemen Keuangan di Pondok Pesantren Menggunakan Aplikasi Berbasis Web Terintregasi Dengan Bercode System dan SMS Gateway. Jurnal Siliwangi Vol. 2 No. 2 ISSN 24776629.

Pernyataan Standar Akuntansi Keuangan (PSAK). 2002. Jakarta: Salemba Empat. Martono. (2010). Manajemen Keuangan Edisi 3. Yogyakarta: Ekonisia.

Wahyuningsih, H. K. (2018). Analisis Pelaporan Keuangan Di yayasan AsSalam Manado (Berdasarkan PSAK 45 dan PSAK 101 ). Jurnal Kajian Ilmiah Akuntansi Fakultas Ekonomi UNTAN (KIAFE).

Yahya, F. A. (2015). Problem Manajemen Pesantren, Sekolah, Madrasah :
Problem Mutu dan Kualitas InputProses-Output. . Jurnal Pendidikan Islam EL-Tarbawi. Vol. VIII No. 1. 